\title{
the development of paraprofessionals in employment work
}

Paraprofessionals in employment work have most recently been concentrated in community action agencies that serve as prime contractors for categorical manpower programs such as Neighborhood Youth Corps, Operation Mainstream, Concentrated Employment Programs, and Work Incentive Programs. Because of budget cutbacks, program restrictions, and impoundment of funds under the Nixon administration, these programs are dying on the vine. As the agencies retrench, paraprofessional workers are among the first to go.

However, under the new Comprehensive Employment and Training Act (CETA), with its decentralization and decategorization, many of these community action agencies are likely to be the ones with which cities and counties contract for the provision of manpower services to disadvantaged populations. CETA is too new for speculation about its impact, but if paraprofessionals are to continue to play a role in employment work, it will be through their employment in CETA-funded agencies.

The establishment of paraprofessionals in employment work took place first in state employment service (ES) agencies and was associated with these agencies' participation in the war on poverty. Yet today, oddly enough, there are few paraprofessionals in state ES agencies, and these agencies are no longer concentrating on the employability of the disadvantaged but rather are returning to their more traditional role
Jesse E. Gordon

Jesse E. Gordon is a Professor of Psychology and Social Work at the University of Michigan in Ann Arbor and President of Manpower Science Services, Inc. Copies of the complete paper on which this article is based can be obtained from the author.

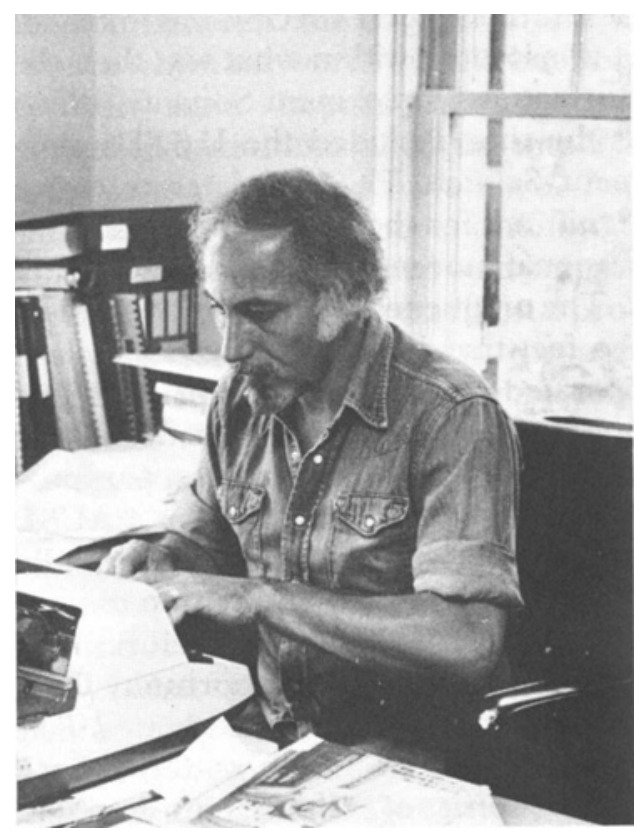


as a labor exchange mechanism for nondisadvantaged workers. This article identifies some of the historical factors that account for the movement of paraprofessionals out of their first homes in state employment service agencies.

\section{PEACE CORPS INFLUENCE}

It was Project CAUSE (Counselor Aide University Summer Education) in 1964 that launched paraprofessionals as a major movement in manpower work. When the Kennedy administration began planning for the war on poverty, it was natural to transfer its youthfulcitizen-activist Peace Corps idea from the international to the national arena. Some Peace Corps staffers were assigned to develop a "domestic Peace Corps," and there began public discussion of the idea-enough discussion to alert resistance. It appeared as if the idea would be stymied, until one of the Peace Corps planners was transferred to the U.S. Department of Labor. There the Manpower Development and Training Act had funds and authorization for projects that could be interpreted to resemble closely the domestic Peace Corps concept. Thus Project CAUSE was initiated. It was located within what was then the Bureau of Employment Security, which at the time included the U.S. Employment Service. This was later to prove significant for the employment paraprofessional movement.

The uniqueness of Project CAUSE was the fact that it was conceived and first operated on the Peace Corps model of nonprofessionals rather than on the rapidly developing indigenous paraprofessional model. Thus, young CAUSE trainees, primarily white and middle class, were recruited and sent to universities for summer training before their assignment to Youth Opportunity Centers to be located in urban ghettos. Following the Peace Corps pattern, there was a spirit of elitism, inspirational rhetoric, commitment to the underdog, and an intense desire to break out of the shell of passivity vis-à-vis local institutions and practices. The location of CAUSE within the U.S. Department of Labor influenced concentration on problems of employment, but it was not a narrow concentration; the new sociological liberalism saw unemployment of the poor as inextricably connected with problems of health, discrimination, education, family structure, and so forth. Indeed, it was this wide view of the problem of youth unemployment that provided CAUSE trainees with a basis for an identity that would distinguish them from employees of traditional institutions and agencies.

While the first CAUSE recruits were in training, a significant decision was made regarding the Youth Opportunity Centers, and this decision had direct impact on the fate of paraprofessionals in employment work. Center operations were administratively located within the U.S. Employment Service. This meant that the centers would be established and managed by state ES agencies and only indirectly responsive to federal direction. In short, the centers would be controlled by the very agencies of which CAUSE was an implicit criticism. Thus, CAUSE trainees passed state civil service examinations and began working in the centers, which looked more like state employment service offices than had been envisioned. Although services at the centers were expanded to include outreach and an interest in clients' lifeproblems beyond getting jobs, they fell under the bureaucratic constraints of systems whose structural characteristics were inconsistent with the crisis intervention tasks for which CAUSE trainees had been prepared.

\section{CHANGE IN SELECTION PROCEDURES}

Another major event further influenced the development of paraprofessionals in 
employment work: The CAUSE selection process, in its second round, became more effectively targeted on blacks and other minorities. In part this was a response to the increasing pace of the civil rights movement and an alliance with it; in part it was a response to other dynamics.

The alliance of CAUSE with the civil rights movement was a natural response to domestic institutions' resistance to the antibureaucratic thrust that CAUSE had inherited from the Peace Corps concept. The resistance had become so great that continuance of CAUSE was seriously threatened by powerful figures in and out of Congress. Personality tests used for selection were seen as unconstitutional invasions of privacy and as means of sneaking "radicals" into the system. Professional groups of counselors, having just succeeded in getting the U.S. Department of Labor to establish higher professional standards for counseling, were up in arms over the introduction of nonprofessionals. They also interpreted CAUSE as an implicit criticism of their role in the vocational development of poor youths. The result of all this criticism was that CAUSE allied itself with civil rights groups as a way to head off attacks.

It is perhaps worth noting that when the Peace Corps concept was applied domestically it stirred deep concern over its threat to established institutional interests and was readily seen as federal interference in local governmental affairs. Ironically, similar efforts by the Peace Corps to change institutions abroad were seen as admirable, and cries of imperialism were dismissed as paranoid nonsense.

The administration of the Youth Opportunity Centers by state agencies also meant that original selection procedures used in the first round had to be changed from the Peace Corps model to the civil service model. Thus personality tests and clinical judgments were eliminated. In lieu of state merit system procedures, CAUSE was required to adopt a test prepared by an agency within the civil service system in order to get states to accept CAUSE selection. In reaction to this requirement, CAUSE added counterbalancing test items and recruitment measures that would make traditional civil service selection unbiased. As a result, 33 percent of the second-round recruits were black, in contrast to 6 percent in the first phase. This process moved employment paraprofessionals closer to the "New Careers for the Poor" model.

\section{NEW CAREER OVERLAY}

This development made the employment paraprofessional into a hybrid: From the original Peace Corps model came the image of paraprofessionals as agents of social change both within the institutions they worked in and within those organizations they came into contact with; and from the New Careers model came the image of paraprofessionals as indigenous workers with inevitably low status in employing organizations. The former model implied an alliance between the worker and the poor in which the worker would have his or her main impact on majoritycontrolled institutions; the latter implied that the worker would have his or her main impact on the poor whom the worker presumably served-an impact as good as or better than traditional professionals had. The process through which these two models became confused was a slow one, and thus some of the resulting internal inconsistencies in the role expectations for paraprofessionals did not become immediately apparent.

It is difficult to describe with any certainty what paraprofessionals did in Youth Opportunity Centers. They tended to be primarily involved in activities that linked the agency to its envi- 
ronment (e.g., outreach to recruit clients and follow-up after client placement in some kind of work training). In many agencies they conducted group orientation. In some agencies they did individual counseling, especially regarding matters other than vocational decision making (home and family problems, social problems, etc.). They were most often used for crisis interventions (accompanying a client to other community service agencies, visiting a client detained by the police, etc.). Finally, in many offices it was difficult to see any task difference between counselors and paraprofessionals, except for a tendency to route minority clients to the paraprofessional rather than the counselorespecially if the paraprofessional was also a minority group member.

\section{IMPACT OF NEW LEGISLATION}

The migration of paraprofessionals out of state ES agencies resulted from a combination of pushes and pulls: The push came from inconsistencies between the paraprofessional movement and the structure of the ES as a formal organization; the pull was the attractiveness of the new war on poverty agencies and organizations that followed passage of the Economic Opportunity Act of 1964. It seems that the establishment of new agencies and organizations under the Office of Economic Opportunity, outside civil service and state merit systems and outside the complex bureaucratic formality of ES, provided an alternative that was more attractive and accessible to CAUSE trainees and would-be CAUSE participants. Within two years there were few CAUSE-trained people left in the ES system, and only a few states maintained and filled civil service classifications for paraprofessionals. Now there are only a handful of Youth Opportunity Centers still in existence around the country.

At the present time the typical pattern of personnel utilization in manpower work has paraprofessionals concentrated in nonstate agencies and programs (typically in categorical manpower programs such as Operation Mainstream, Neighborhood Youth Corps, New Careers, and public service employment programs) administered under contracts to community action agencies and subcontracts to other community-based organizations such as church organizations and YM-YWCAs. In joint programs such as Concentrated Employment Programs, in which a community action agency is more or less required to subcontract with the state $\mathrm{ES}$ for certain service delivery functions, paraprofessionals are employed by the community action agency and professionals by the ES.

\section{SUMMING UP}

This historical account has emphasized several points. First, the paraprofessional movement in employment work represented a "people innovation" (Zaltman, Duncan \& Holbek 1973) in which an effort was made to change the policy, structure, and functions of employment institutions by changing the people who carried out policy. Second, the sources of the movement confused the Peace Corps and the New Careers models, producing inconsistencies in the role expectations for paraprofessionals; this confusion was itself a product of political factors called into play by the "people innovation" effort. Third, there were fundamental incompatibilities between the demands of the tasks to be carried out under the new antipoverty policies (to have individual, personalized relationships with clients) and the demands of the bureaucratic structure of the agencies in which these tasks were placed (to treat clients in standardized, routine ways).

In sum, the fate of the paraprofessional movement in employment work 
was controlled by internal contradictions in the origins of the movement, by the structure of the agencies in which they were placed, and by successful resistance to changing institutions. The tragedy is that so many paraprofessionals and their critics interpreted that fate as a reflection on the personal capabilities of the paraprofessionals themselves.

\section{REFERENCE}

Zaltman, G.; Duncan, R.; \& Holbek, J. Innovations and organizations. New York: Wiley, 1973. 